\title{
Advanced therapy medicinal products and exemptions to the Regulation 1394/2007: how confident can we be? An exploratory analysis
}

\section{Philippe Van Wilder *}

TiGenix NV, Leuven, Belgium

\section{Edited by:}

Iñaki Gutiérrez-Ibarluzea, Basque Office for Health Technology

Assessment, Spain

\section{Reviewed by:}

Dominique J. Dubois, Université Libre de Bruxelles, Belgium

Suyash Prasad, BioMarin

Pharmaceutical, USA

\section{*Correspondence}

Philippe Van Wilder, TiGenix NV, Researchpark Haasrode 1724,

Romeinse straat 12, bus 2, 3001 Leuven, Belgium.

e-mail:philippe.vanwilder@ tigenix.com

\begin{abstract}
The market authorization procedure for medicinal products for human use is relying on their demonstrated efficacy, safety, and pharmaceutical quality. This applies to all medicinal products whether of chemical or biological origin. Since October 2009, the first advanced therapy medicinal product (ATMP) has been authorized through the centralized procedure. ATMPs are gene therapy medicinal products, somatic cell therapy medicinal products or tissue-engineered products. An appropriate ATMP - Regulation is dealing with ATMP requirements. Two exemptions are foreseen to the ATMP Regulation: (a) Products, which were legally on the Community market when the Regulation became applicable, should comply to the Regulation by December 30, 2012. (b) The hospital exemption rule for non-routine products for an individual patient. In this work we explored whether the actual application of the Regulation on ATMPs is in line with the aim of the Regulation in terms of guaranteeing the highest level of health protection for patients. Based on the analysis of the relative efficacy of the only EC authorized ATMP and its exempted alternatives, there is evidence against this Regulation 1394/2007 assumption.
\end{abstract}

Keywords: advanced therapy, Regulation 1394/2007, exemption, patient outcome

\section{INTRODUCTION}

The market authorization (MA) procedure for medicinal products for human use is relying on their demonstrated efficacy, safety, and pharmaceutical quality (The European Parliament and the Council of the European Union, 2001). This applies to all medicinal products whether of chemical (e.g., blood pressure lowering diuretic) or biological (e.g., anti-inflammatory monoclonal antibody) origin. Modern biotechnology medicinal products obtain market approval through the centralized procedure as detailed in the EC Regulation 726/2004 (The European Parliament and the Council of the European Union, 2004).

Since 2008, a "lex specialis" - Regulation (EC) No 1394/2007 (The European Parliament and the Council of the European Union, 2007) - applies to advanced therapy medicinal products (ATMPs); these ATMPs are pharmaceuticals with high complexity (The Committee for Advanced Therapies (CAT) and the CAT Scientific Secretariat, 2010) linked to their development, manufacturing, or administration process.

The Regulation highlights the following:

- It provides an explicit ATMP definition: ATMPs are gene therapy, somatic cell therapy, or tissue-engineered medicinal products.

- An ATMP must comply with the existing MA requirements (quality, safety, and efficacy) and the post-marketing pharmacovigilance rules. For MA, the centralized procedure is mandatory: it aims to pool Community expertise and ensure a high level of scientific evaluation and facilitate access to market.
- Because of the complexity of ATMPs, a new Committee for Advanced Therapies (CAT) has been installed. The CAT's main responsibilities are:

- The mandatory evaluation of MA applications by providing opinions to the Committee for Medicinal Products for Human Use (CHMP); the CHMP may adopt or refuse the CAT opinion.

- The optional scientific certification (art. 18) of quality and non-clinical data of a proposed ATMP-compound in development.

- The optional scientific recommendation on ATMPclassification (art. 17), prior to their clinical development.

The CAT (The Committee for Advanced Therapies (CAT) and the CAT Scientific Secretariat, 2010) is a multidisciplinary scientific expert committee: it also focuses on the scientific developments in the field. There is no doubt about the huge scientific, regulatory, and ethical challenges triggered by these complex products and a specific expert committee for ATMPs is necessary to deal with these challenges (similar to the creation of the Committee on Orphan Medicinal Products for drugs used in rare diseases) and beneficial to all relevant public and private stakeholders.

- The Tissues and Cells Directive (2004/23/EC) applies to donation, procurement and testing of human tissues and cells.

- The Regulation defines the pre- and post-authorization requirements: GMP and GCP standards, product follow-up on efficacy and safety, risk management plan, and traceability. 
- The Regulation also provides incentives for applicants by offering scientific advice at various development steps at substantially reduced fees, mainly to small- and medium-sized enterprises and hospitals.

The aim of this ATMP - Regulation is to offer a consolidated regulatory framework for these innovative medicines and it was designed (European Medicines Agency, 2011a) to

"... ensure the free movement of these medicines within the European Union (EU), to facilitate their access to the EU market, and to foster the competitiveness of European pharmaceutical companies in the field, while guaranteeing the highest level of health protection for patients."

Two exemptions are foreseen to the ATMP Regulation:

1. Products, which were legally on the Community market on December 30, 2008 (when the Regulation became applicable), should be compliant to the Regulation requirements no later than December 30, 2012. These products will be withdrawn from the market afterward if no centralized MA application has been submitted and granted.

2. Exemptions to the Regulation are also defined under the hospital exemption rule:

"Advanced therapy medicinal products which are prepared on a non-routine basis according to specific quality standards, and used within the same Member State in a hospital under the exclusive professional responsibility of a medical practitioner, in order to comply with an individual medical prescription for a custom-made product for an individual patient, should be excluded from the scope of this Regulation whilst at the same time ensuring that relevant Community rules related to quality and safety are not undermined."

The first exemption relates to a transition period allowing existing products to evolve toward ATMP-compliance. The hospital exemption allows hospitals and medical practitioners to provide ATMP-classified products to patients, e.g., in case of high unmet medical need because there is no authorized ATMP alternative available. Concrete examples are tumor vaccines, made by hospitals for treating cancer patients having no treatment alternatives.

The hospital exemption is limited to non-routine products, custom-made for individual patients. There is discussion on the correct interpretation of these words: for instance, are autologous products de facto not for individual patients?

Anyway, as a consequence, ATMPs with different development tracks and quality control procedures may co-exist on the Community market satisfying different standards on efficacy, safety and quality; for hospital exemptions the Regulation requires traceability, quality, and pharmaco-vigilance standards to be "equivalent" to standards for centrally authorized products. Manufacture of ATMPs under hospital exemption has to be authorized by the appropriate member state to ensure appropriate quality. There are no efficacy criteria mentioned.

Even if there are good reasons explaining why these exemptions are needed (e.g., the realism of a transition period, the ethical need to deal with unmet medical need) the Regulation allows exemptions on the market without concrete requirement on demonstrated quality, efficacy, and safety.

\section{OBJECTIVES}

In this work we explored whether the actual application of the Regulation on ATMPs is in line with the aim of the Regulation in terms of guaranteeing the highest level of health protection for patients by focusing on ATMPs and their exemptions. Health protection is understood as ensuring efficacy, safety, and pharmaceutical quality.

The aim is exploratory only: it intends to enhance the discussion on the effectiveness of the Regulation, based on early experience. This work does not pretend to provide judicious and definite answers to the complex economic and ethical issues relating to regulatory exemptions.

\section{METHODS}

We searched the available evidence for ATMP products being centrally authorized (EC authorized) and for their available alternatives (non-EC authorized, exemptions). We started by checking the EMA-website (European Medicines Agency, 2012) for authorized ATMPs till December 2011. We then searched the medical literature published on "EC authorized" and on "non-EC authorized" ATMPs. Due to the exploratory purpose, we did not make an exhaustive systematic literature search as would be required for a formal health technology assessment: our interest was not to focus on the performance of a single product but to explore whether clinically relevant differences might exist between products, which if it was the case would be considered as a threat to the aim of the Regulation of guaranteeing the highest level of health protection for patients.

Many competing interventions have not been compared directly: because the literature search ended with only one ATMP being available as EC authorized product and we did not find trials with head-to-head comparisons (see Results) between "EC authorized" and "non-EC authorized" ATMPs, we performed adjusted indirect treatment comparisons (ITCs). The on line application provided by the Canadian Agency for Drugs and Technologies in Health (CADTH; Canadian Agency for Drugs and Technologies in Health, 2011) was used; this public available Agency's application is based on appropriate methodology for adjusted comparisons, with an explicit user guide offering step by step assistance in the analysis. The ITC application can cope with simple and more complex (multiple comparisons) settings; in this work we simply analyzed the EC authorized ATMP with each of the non-EC authorized ATMPs based on a common comparator.

The main ITC assumption of independence among trials was achieved by excluding published study results if they originated from the same study populations.

The evidence found in the literature used different clinical endpoints per trial. Only standardized treatment effects could then be used for ITC, losing the clinical relevance of the individual endpoints: to cope for this loss, we considered the strength of the effect as categorized by Cohen (Valentine and Cooper, 2003) to approximate the clinical relevance of the results. The strength of the Cohen effect size is generally classified as follows: small effect if difference 
$\geq 0.2$, medium effect if difference $\geq 0.5$, and large effect if difference $\geq 0.8$. We assumed that "large effects" would be considered clinically relevant effects.

No adjustment was done for multiple testing: the significance level was set at 0.05 .

\section{RESULTS}

Despite the Regulation being implemented by the end of 2008, only six applications have been submitted for MA of four ATMPs (European Medicines Agency, 2012):

- In June 2009 a positive opinion for MA was adopted for ChondroCelect, which is an autologous product containing chondrocytes for treatment of deep cartilage injuries of the knee.

- In July 2009, the product Contusugene Ladenovec was withdrawn by the applicant: the product was intended for treatment of squamous cell carcinoma of head and neck.

- In December 2009, the CAT adopted a negative opinion on the MA application of Cerepro, a gene therapy product intended for treatment of cerebral cancer (high grade glioma); the manufacturer withdrew its application in March 2010.

- A negative CAT opinion was adopted for the MA application of Glybera in June 2011; Glybera is a gene therapy product intended for use in severe lipid metabolic disease. On reexamination of Glybera in October 2011, the CAT adopted a positive opinion but this was not endorsed by the CHMP.

Market authorization was granted by the Commission in October 2009 for ChondroCelect (TiGenix company; European Medicines Agency, 2011b), indicated for the repair of knee cartilage defects.

Osteoarthritis (OA) is a public health concern (Clouet et al., 2009): during OA degenerative processes, major modifications of articular cartilage are observed at the tissue, cellular, and molecular levels. Articular cartilage, if damaged, hardly heals, and traumatic loss of cartilaginous tissue therefore may lead to the subsequent development of OA-lesions (e.g. of knee, hip...). The therapeutic options combine pharmacological treatments and tissue engineering toward regenerative medicine to induce cartilage repair.

ChondroCelect is still the only EC authorized ATMP: non-EC authorized chondrocytes for knee cartilage repair also exist. All chondrocyte products are implanted in the patient knee by a surgical technique called autologous chondrocytes implantation (ACI). In this work we will further identify these products as either CCI (for EC authorized chondrocytes, ATMP) and ACI (for non-EC authorized chondrocytes).

A simplified search in PubMed (August 18, 2011) was performed using the key words "autologous chondrocyte," limiting the search to controlled trials on human beings and further limited to papers published in English between 2008 (implementation year of the Regulation on ATMPs) and mid august 2011. The PubMed literature search resulted in 50 references (see Appendix).

Because the control group in the clinical development (European Medicines Agency, 2011c) program of CCI was microfracture (a surgical micro-bleeding technique releasing stem cells), only
ACI-studies including microfracture (MF) as control group could be selected for making ITC between the clinical outcome of CCI and ACI.

Across the studies a variety of clinical end-points was used with only some being considered as validated end-points for clinical research by EMA (The Committee for Advanced Therapies, 2010).

From the 50 references, only four papers on three studies included clinical results from ACI and MF: 45 papers were excluded because the study included only observational noncontrolled data, because the study related to subgroups from the three main studies, because lack of (knee) clinical outcome results or because another comparator than MF was used. There was one systematic review (Harris et al., 2010) which included the results of the three identified primary studies. Moreover, the review authors took care of standardizing the clinical outcome results of the included trials which is particularly relevant because the variety of clinical and structural end-points (The Committee for Advanced Therapies, 2010) used in the included studies would otherwise be a hurdle to any meaningful quantitative analysis.

For making ITCs between CCI and each of the various ACIproducts, the standardized results of the systematic review were subsequently used.

The review authors included seven trial reports on $>900$ patients in which CCI and ACI-products were compared to MF. In our opinion, for two trials, the results of the same patient population were presented at two different lengths of follow-up: to obtain independent trial data, only one manuscript (the most recent one) per patient population was kept, resulting in five datasets for further comparison.

Indirect treatment comparisons can only be valuable if the compared patient populations across trials are similar (Jansen et al., 2011) with respect to modifiers of the relative treatment effect (e.g., important prognostic factors): because MF is the common comparator the appropriateness of the trial patient population with respect to the lesion size needs to be addressed. One study (reference Basad et al., 2010 in the review) was excluded because it enrolled patients with cartilage lesions larger than $4 \mathrm{~cm}^{2}$, which are commonly accepted to be unsuitable for MF treatment (The Committee for Advanced Therapies, 2010).

Accordingly, the standardized results from four products $(\mathrm{CCI}$, ACI 1-3) were compared.

The standardized direct mean treatment differences and the 95\% CI of the mean differences between the various chondrocyte products and MF are as follows (extracted from p. 2226 of Harris et al., 2010).

\begin{tabular}{lcl}
\hline $\begin{array}{l}\text { Product (reference as } \\
\text { mentioned in the } \\
\text { systematic review) }\end{array}$ & $\begin{array}{l}\text { Standardized mean } \\
\text { treatment difference } \\
\text { with MF }\end{array}$ & $\begin{array}{l}\mathbf{9 5 \%} \text { Confidence } \\
\text { interval }\end{array}$ \\
\hline $\mathrm{CCl}$ (Saris et al., 2009) & 1.52 & $(1.03 ; 2.01)$ \\
$\mathrm{ACl} 1$ (Kon et al., 2009) & 0.76 & $(0.31 ; 1.21)$ \\
$\mathrm{ACl} 2$ (Basad et al., 2004) & 0.92 & $(-0.06 ; 1.82)$ \\
$\mathrm{ACl} 3$ (Knutsen et al., 2007) & -0.40 & $(-0.79 ; 0.01)$
\end{tabular}


Two of the four chondrocyte products could demonstrate significant clinical benefit as compared to MF (CCI, ACI1): the standardized mean treatment difference could be classified as "large effect." The lower limit of the confidence interval of the CCI standardized clinical effect still exceeded the "large effect" threshold; both ACI2 and ACI3 products had a non-significant mean difference with MF but their confidence intervals still include "large effect" sizes.

Based on the individual study results versus MF, the ITC between the chondrocyte products could be computed and are summarized as follows (see statistical output from CADHT-tool in Appendix).

\begin{tabular}{llll}
\hline Treatment effect & Estimate of mean $\boldsymbol{\Delta}$ & $\mathbf{9 5 \%} \mathbf{L C L}$ & $\mathbf{9 5 \%} \mathbf{U C L}$ \\
\hline $\mathrm{CCl}-\mathrm{ACl} 1$ & $\mathbf{0 . 7 6}$ & 0.095 & 1.425 \\
$\mathrm{CCl}-\mathrm{ACl} 2$ & 0.60 & -0.460 & 1.660 \\
$\mathrm{CCl}-\mathrm{ACl} 3$ & $\mathbf{1 . 9 2}$ & 1.287 & 2.553 \\
$\mathrm{ACl} 1-\mathrm{ACl} 2$ & -0.16 & -1.202 & 0.882 \\
$\mathrm{ACl} 1-\mathrm{ACl} 3$ & $\mathbf{1 . 1 6}$ & 0.558 & 1.762 \\
$\mathrm{ACl} 2-\mathrm{ACl} 3$ & $\mathbf{1 . 3 2}$ & 0.298 & 2.342
\end{tabular}

The bold significance relates to any statistically significant effect being 0.8 or higher, as this is the threshold of large treatment effects (Cohen effect size).

From the six possible ITCs four ITCs yield significant differences: CCI is significantly superior to ACI1; CCI, ACI1, and ACI2 are significantly superior to ACI3. All significant mean differences can be classified as "large" treatment effects.

\section{DISCUSSION}

Advanced therapy medicinal products are human cells and tissues or products with a genetic mode of action; they generate huge expectations but are also associated to new significant threats [The Committee for Advanced Therapies (CAT) and the CAT Scientific Secretariat, 2010] including tumorigenicity, cell (de)differentiation, and patient integration. The ATMP Regulation $1394 / 2007$ aims to facilitate the patient access to these products and to foster the competitiveness of European pharmaceutical companies in the field, while guaranteeing the highest level of health protection for patients.

The ATMP-portfolio for which the CAT has been involved in certification, classification, and MA is available via the monthly CAT-reports (European Medicines Agency, 2012):

- By the end of 2011 only one certification procedure for quality and non-clinical data has been requested (2009) and adopted (2010).

- Fifty-three requests for ATMP-classification have been submitted of which 51 reached the recommendation stage: $46(90.2 \%)$ have been classified ATMP.

- Six applications for MA of four products have been evaluated leading to one authorized ATMP.

The certification procedure intends to create incentives for SMEs to develop ATMPs; the only certification procedure finished by now clearly threatens this objective. Fortunately, the number of submitted ATMP-classification requests is sufficiently large to identify the actual main areas for ATMP-development in Europe.
Among the 46 ATMP-classified products (available from website):

- Seventeen $(37.0 \%)$ are somatic cell therapy products.

- Seventeen $(37.0 \%)$ are tissue-engineered products.

- Eleven $(23.9 \%)$ are genetic therapy products.

- One $(2.1 \%)$ is classified as ATMP without further specification.

The split per therapeutic area is as follows:

\begin{tabular}{|c|c|c|c|c|c|}
\hline $\begin{array}{l}\text { Disease: } \\
\text { ATMP }\end{array}$ & Cancer & $\begin{array}{l}\text { Cardio- } \\
\text { vascular }\end{array}$ & $\begin{array}{l}\text { Inflammatory } \\
\text { and auto- } \\
\text { immune }\end{array}$ & Skin & Other \\
\hline $\begin{array}{l}\text { Somatic cell } \\
\text { therapy }\end{array}$ & 8 & 1 & 4 & 1 & 3 \\
\hline $\begin{array}{l}\text { Tissue } \\
\text { engineered }\end{array}$ & 1 & 5 & & 4 & 7 \\
\hline Gene therapy & 3 & & 1 & & 7 \\
\hline Total (\%) & $12(26.7)$ & $6(13.3)$ & $5(11.1)$ & $5(11.1)$ & 17 (37.8) \\
\hline
\end{tabular}

The oncology area captures 12 ATMPs mainly classified as somatic cell (8) therapy. Cell compounds for treatment of debilitating inflammatory (e.g., multiple sclerosis) or auto-immune diseases (e.g., pancreatitis) and tissue-engineered products for use in severe cardiovascular disease (e.g., myocardial infarction) or skin disease (mainly treatment of burn wounds) are in development; applications are studied in metabolic disease, ophthalmology, bone, and cartilage disease, but also in muscular, and neurological disease (e.g., Parkinson disease).

Clearly, these are therapeutic areas with a huge disease burden, linked to a high unmet medical need in which ATMPs may be of value by their unique mode of action, aiming at regenerating cell functionality, and tissue integrity.

After 4 years the net outcome of the ATMP Regulation $1394 / 2007$ is still limited as only one ATMP has been authorized and only one request for certification has been finalized, despite the fact that already 46 compounds have been classified as ATMP. In the US, the Center for Biologics Evaluation and Research (CBER; Food and Drug Administration, 2012a) within FDA regulates biological products for human use, both investigational and licensed. CBER regulates biological products including gene therapy, human tissue, and cells under applicable federal laws, including the Public Health Service Act and the Federal Food, Drug and Cosmetic Act. By now, no gene therapy has been authorized to market but various human tissue (Food and Drug Administration, 2012b) and cell products are authorized including the autologous cellular immunotherapy product Provenge (Dendreon company) for treatment of prostate cancer and the cultured chondrocytes product Carticel (Genzyme company). There is no "lex specialis."

Exemptions, specific to the European Regulation include a temporary exemption (till end of 2012) for products existing prior to the implementation of the Regulation and a permanent hospital exemption for non-routinely made products for individual patients. In this work we aimed to verify whether different development tracks for these complex medicinal products are not putting 
the patient health protection (defined as ensuring efficacy, safety, and pharmaceutical quality) at risk.

The only ATMP authorized in the Community market is a medicinal product containing chondrocytes for knee cartilage regeneration.

Based on the literature search on the "EC authorized" and "non-EC authorized" chondrocyte products, ITC could be made between four different products. Our results indicate statistically significant and clinically relevant differences in efficacy exist between these four cell products.

The Regulation 1394 is based on the assumption that "EC authorized" and exempted ATMPs provide similar health patient benefit. But based on our indirect results, the probability of a healthy patient outcome is strongly dependent on the product administered; this puts the exemption rule of the Regulation under pressure.

From a pharmacological point of view, similar (the highest) health patient benefit among exempted and non-exempted ATMPs is assuming there would be a class effect (acknowledging this may be a difficult concept for autologous products). But even for a class of conventional medicinal products like ACE-inhibitors, quantitative differences altering the therapeutic benefits for specific patient populations may exist as shown by Furberg (2000); the author's conclusion was that untested drugs of a class should be considered unproven drugs. If this is the case for conventional medicinal products, how confident can we then be in assuming that the highest health benefit will be ensured between more complex medicinal products?

Finally, more specifically in the orthopedic surgery field, the review by Vavken and Samartzis (2010) did mention: “. . .Also ACI can hardly be seen as one, standardized treatment, due to technical differences, and inter-patient variation in cell quality."

Based on the above, in the therapeutic area of orthopedic surgery, there is evidence to say clinically relevant differences in health outcome exist between the authorized ATMP and the exemption products.

This study has many limitations. Only one medicinal product could be investigated despite the Regulation being applicable from the end of 2008 .

The evidence on different health outcome benefits between the ATMP and its exemption products is based on ITC from one recent systematic review in the orthopedic surgery field. There is a lack of controlled trials with acceptable quality in this area (Hanzlik et al., 2009): in a review of all articles published in The Journal of Bone and Joint Surgery in the years 1975, 1985, 1995, and 2005 the percentage of Level-I studies increased from $4 \%$ in 1975 to $21 \%$ in 2005. Despite this positive trend for increasing the percentage of high level evidence trials there is still substantial opportunity for improvement.

The individual clinical trial end-points were transformed into one standardized outcome affecting the interpretation of clinical relevance: to deal with this, we used the common cut-off for large treatment effects to identify clinical relevant effects.

We analyzed efficacy and did not focus on other elements of patient health benefit like safety or pharmaceutical quality. Investigating differences in safety issues might be very hard because of the small number of patients enrolled in the considered studies (maximum of 118 patients randomized): the estimate of the incidence of adverse events for any compound will lack precision. Differences in pharmaceutical quality could not be investigated because of lack of public available documentation. It is a clear advantage of EC centrally authorized medicinal products that important regulatory documentation is easily available: the summary of product characteristics (SPC) and the European public assessment report (EPAR) provide relevant insights to patient and health care worker on efficacy, safety, and pharmaceutical quality of the medicinal product. The extent of documentation on non-EC authorized products is differing between member states, delivering companies or hospitals, and may be hard to obtain for any external party.

We did not analyze how exemptions to ATMPs may affect the internal market functioning because of the limited experience with only one ATMP available. Obviously differences in development track will yield differences in the necessary R\&D resources, which may result in substantial product price differences: this is a hurdle for the applicant submitting a centrally authorized ATMP when lower priced exempted alternatives are on the market. In many member states a price premium can only be granted if added therapeutic value compared to the alternative has been demonstrated. But this direct comparison will probably lack, as it is the case for the 1st ATMP containing cultured chondrocytes: the design section of the CAT-Reflection Paper (The Committee for Advanced Therapies, 2010) in this field clearly specifies "licensed products" as valid comparators that can be used in controlled trials. It further states "... However, the use of a nonauthorized medicinal product is problematic as it has not been validated for clinical use and the quality of the product has not been assessed."

Valid approaches to adjusted ITC will be necessary but the acceptability of indirect evidence may be different between competent authorities increasing the 4th hurdle for ATMPs.

As the European Pharmaceutical Forum and the European Transparency Directive (The Council of the European Communities, 1989; European Commission, 2012) explicitly ask competent authorities on pricing and reimbursement to take decisions based on objective and verifiable criteria and to be well aligned with the estimated value of medicines, the question may arise how these member states will determine the relative value of an ATMP in comparison to exempted alternatives with assumed but unproven effect.

In conclusion, based on the analysis of the relative efficacy of the only EC authorized ATMP and its exempted alternatives, there is evidence against the Regulation 1394/2007 assumption of ensuring the highest level of patient health protection is maintained among each of these products. The ethical need for exemption must be balanced with the upcoming evidence of differences in health outcome between EC authorized and non-EC authorized ATMP products. The scheduled review by the Commission by the end of 2012 of the application of the Regulation should include an assessment of the likelihood of similar health outcome among ATMPs with different development tracks. 


\section{REFERENCES}

Basad, E., Ishaque, B., Bachmann, G., Stürz, H., and Steinmeyer, J. (2010). Matrix-induced autologous chondrocyte implantation versus microfracture in the treatment of cartilage defects of the knee: a 2-year randomised study. Knee Surg. Sports Traumatol. Arthrosc. 18, 519-527.

Basad, E., Sturz, H., and Steinmeyer, J. (2004). Die behandlung chondraler Defekte mit MACI oder Microfracture-erste Ergebnisse einer vergleichenden klinischen Studie. Orthopadische Praxis. 40, 6-10.

Canadian Agency for Drugs and Technologies in Health. (2011). Indirect Treatment Comparisons. Accessed September 2. Available at: http:// www.cadth.ca/en/products/metho ds-and-guidelines/publication/884

Clouet, J., Vinatier, C., Merceron, C., Pot-vaucel, M., Maugars, Y., Weiss, P., Grimandi, G., and Guicheux, J. (2009). From OA treatments to future regenerative therapies for cartilage. Drug Discov. Today 14, 913-925.

European Commission. (2012). Accessed January 2. Available at: http://ec.europa.eu/pharmaforum/ docs/final_conclusions_en.pdf

European Medicines Agency. (2011a). Accessed August 3. Available at: http://www.ema.europa.eu/ema/in dex.jsp?curl=pages/regulation/gener al/general_content_000295.jsp\&mu $\mathrm{rl}=$ menus/regulations/regulations. jsp\&mid=WC0b01ac058007f4bb

European Medicines Agency. (2011b). Accessed August 3. Available at: http://www.ema.europa.eu/docs/en GB/document_library/EPAR_-_Pub lic_assessment_report/human/0008 78/WC500026035.pdf

European Medicines Agency. (2011c). Accessed August 3. Available at: http://www.ema.europa.eu/ema/ind ex.jsp?curl=pages $/$ medicines/huma n/medicines/000878/human_med_ 000698.jsp\&murl=menus/medicin es/medicines.jsp\&mid=WC0b01ac0 58001d 124

European Medicines Agency. (2012). Accessed January 2. Available at: http://www.ema.europa.eu/ema/ind ex.jsp?curl=pages/news_and_events /document_listing/document_listi ng_000196.jsp\&mid=WC0b01ac05 $800292 \mathrm{a} 8$

Food and Drug Administration. (2012a). Accessed January 2. Available at: http://www.fda.gov/ AboutFDA/CentersOffices/Officeof MedicalProductsandTobacco/CBER /ucm133072.htm

Food and Drug Administration. (2012b). Accessed January 2. Available at: http://www.fda.gov/ BiologicsBloodVaccines/CellularGe neTherapyProducts/default.htm

Furberg, C. D. (2000). Class effects, and evidence-based medicine. Clin. Cardiol. 23, 15-19.

Hanzlik, S., Mahabir, R. C., Baynosa R. C., and Khiabani, K. T. (2009). Levels of evidence in research published in the Journal of Bone and Joint Surgery (American volume) over the last thirty years. J. Bone Joint Surg. Am. 91, 425-428.

Harris, J. D., Siston, R. A., Pan, X., and Flanigan, D. C. (2010). Autologous chondrocyte implantation: a systematic review. Am. J. Bone Joint Surg. 92, 2220-2233.

Jansen, J. P., Fleurence, R., Devine, B., Itzler, R., Barrett, A., Hawkins, N., Lee, K., Boersma, C., Annemans, L., and Cappelleri, J. C. (2011). Interpreting indirect treatment comparisons, and network metaanalysis for health-care decision making: report of the ispor task force on indirect treatment comparisons good research practices: part 1. Value Health 14, 417-428.

Knutsen, G., Drogset, J. O., Engebretsen, L., Grøntvedt, T., Isaksen, V.,
Ludvigsen, T. C., Roberts, S., Solheim, E., Strand, T., and Johansen, O. (2007). A randomized trial comparing autologous chondrocyte implantation with microfracture. Findings at 5 years. J. Bone Joint Surg. Am. 89, 2105-2112.

Kon, E., Gobbi, A., Filardo, G. Delcogliano, A., Zaffagnini, S., and Marcacci, M. (2009). Arthroscopic second-generation autologous chondrocyte implantation compared with microfracture for chondral lesions of the knee: prospective nonrandomized study at 5 years. Am. J. Sports Med. 37, 33-41.

Saris, D. B., Vanlauwe, J., Victor, J., Almqvist, K. F., Verdonk, R., Bellemans, J., Luyten, F. P., and TIG/ACT/01/2000\&EXT Study Group. (2009). Treatment of symptomatic cartilage defects of the knee: characterized chondrocyte implantation results in better clinical outcome at 36 months in a randomized trial compared to microfracture. Am. J. Sports Med. 37(Suppl. 1), 10S-19S.

The Committee for Advanced Therapies. (2010). Reflection Paper on In-Vitro Cultured Chondrocyte Containing Products For Cartilage Repair of the Knee. Available at: http:// www.ema.europa.eu/docs/en_GB/ document_library/Scientific_guide line/2010/05/WC500090887.pdf

The Committee for Advanced Therapies (CAT) and the CAT Scientific Secretariat. (2010). Challenges with advanced therapy medicinal products and how to meet them. Nat. Rev. Drug Discov. 9, 195-202.

The Council of the European Communities. (1989). Directive 89/105/EEC. OJ L40, 8-11.

The European Parliament and the Council of the European Union. (2004). Regulation
(EC) No. 726/2004. OJ L136, $1-33$.

The European Parliament and the Council of the European Union. (2007). Regulation. (EC) No. 1394/2007. OJ L324, 121-137.

The European Parliament and the Council of the European Union. (2001). Directive 2001/83/EC. OJ L311, 67-128.

Valentine, J. C., and Cooper, H. (2003). Effect Size Substantive Interpretation Guidelines: Issues in the Interpretation of Effect Sizes. Washington, DC: What Works Clearinghouse.

Vavken, P., and Samartzis, D. (2010). Effectiveness of autologous chondrocyte implantation in cartilage repair of the knee: a systematic review of controlled trials. Osteoarthr. Cartil. 18, 857-863.

Conflict of Interest Statement: The author declares to be an employee of TiGenix NV, Belgium.

Received: 03 September 2011; accepted: 19 January 2012; published online: 14 February 2012.

Citation: Van Wilder P (2012) Advanced therapy medicinal products and exemptions to the Regulation 1394/2007: how confident can we be? An exploratory analysis. Front. Pharmacol. 3:12. doi 10.3389/fphar.2012.00012

This article was submitted to Frontiers in Pharmaceutical Medicine and Outcomes Research, a specialty of Frontiers in Pharmacology.

Copyright () 2012 Van Wilder. This is an open-access article distributed under the terms of the Creative Commons Attribution Non Commercial License, which permits non-commercial use, distribution, and reproduction in other forums, provided the original authors and source are credited. 


\section{APPENDIX \\ RESULTS FROM THE ITC PERFORMED WITH THE CADHT-APPLICATION}

CCI-ACI1

Estimate, 95\% LCL, 95\% UCL, Reverse

$1.52, \quad 1.03, \quad 2.01, \quad \mathrm{n}$

0.76, $\quad 0.31, \quad 1.21, \quad \mathrm{y}$

Indirect Estimate: Treatments $(1,3)$

Effect measure: Mean Difference Estimate: 0.76

95\% Confidence interval: 0.095, 1.425

\section{CCI-ACI2}

Estimate, 95\% LCL, 95\% UCL, Reverse

0.92, $\quad-0.06, \quad 1.82, \quad \mathrm{y}$

$1.52, \quad 1.03, \quad 2.01, \quad \mathrm{n}$

Indirect Estimate: Treatments $(1,3)$

Effect measure: Mean Difference Estimate: 0.6

95\% Confidence interval: $-0.46,1.66$

\section{CCI-ACI3}

Estimate, 95\% LCL, 95\% UCL, Reverse 1.52, $1.03, \quad 2.01, \quad \mathrm{n}$

$-0.4, \quad-0.79, \quad 0.01, \quad y$

Indirect Estimate: Treatments $(1,3)$

Effect measure: Mean Difference Estimate: 1.92

95\% Confidence interval: 1.287, 2.553

\section{ACI1-ACI2}

Estimate, 95\% LCL， 95\% UCL， Reverse

$0.92, \quad-0.06, \quad 1.82, \quad \mathrm{y}$

$0.76, \quad 0.31, \quad 1.21, \quad \mathrm{n}$

Indirect Estimate: Treatments $(1,3)$

Effect measure: Mean Difference Estimate: -0.16

95\% Confidence interval: $-1.202,0.882$

ACI1-ACI3

Estimate, 95\% LCL， 95\% UCL， Reverse

0.76, $\quad 0.31, \quad 1.21, \quad \mathrm{n}$

$-0.4, \quad-0.79, \quad 0.01, \quad y$

Indirect Estimate: Treatments $(1,3)$

Effect measure: Mean Difference Estimate: 1.16

95\% Confidence interval: 0.558, 1.762

ACI2-ACI3

Estimate, 95\% LCL, 95\% UCL, Reverse $0.92, \quad-0.06, \quad 1.82, \quad \mathrm{n}$

$-0.4, \quad-0.79, \quad 0.01, \mathrm{y}$

Indirect Estimate: Treatments $(1,3)$

Effect measure: Mean Difference Estimate: 1.32

95\% Confidence interval: 0.298, 2.342 


\section{REFERENCES FROM THE PUBMED LITERATURE SEARCH}

Alberti, C. (2009). Tissue engineering technologies: just a quick note about transplantation of bioengineered donor trachea and augmentation cystoplasty by de novo engineered bladder tissue. G. Chir. 30, 514-519.

Assche, D. V., Caspel, D. V., Staes, F., Saris, D. B., Bellemans, J., Vanlauwe, J., and Luyten, F. P. (2011). Implementing one standardized rehabilitation protocol following autologous chondrocyte implantation or microfracture in the knee results in comparable physical therapy management. Physiother. Theory Pract. 27, 125-136.

Basad, E., Ishaque, B., Bachmann, G., Stürz, H., and Steinmeyer, J. (2010). Matrix-induced autologous chondrocyte implantation versus microfracture in the treatment of cartilage defects of the knee: a 2-year randomised study. Knee Surg. Sports Traumatol. Arthrosc. 18, 519-527.

Bekkers, J. E., Inklaar, M., and Saris, D. B. (2009). Treatment selection in articular cartilage lesions of the knee: a systematic review. Am. J. Sports Med. 37(Suppl. 1), 148S-55S.

Brun, P., Dickinson, S. C., Zavan, B., Cortivo, R., Hollander, A. P., and Abatangelo, G. (2008). Characteristics of repair tissue in secondlook and third-look biopsies from patients treated with engineered cartilage: relationship to symptomatology and time after implantation. Arthritis Res. Ther. 10, R132.

Candrian, C., Bonacina, E., Frueh, J. A., Vonwil, D., Dickinson, S., Wirz, D., Heberer, M., Jakob, M., Martin, I., and Barbero, A. (2009). Intra-individual comparison of human ankle and knee chondrocytes in vitro: relevance for talar cartilage repair. Osteoarthr. Cartil. 17, 489-496.

Choi, Y. S., Potter, H. G., and Chun, T. J. (2008). MR imaging of cartilage repair in the knee and ankle. Radiographics 28, 1043-1059.

Chubinskaya, S., Hakimiyan, A. A., Rappoport, L., Yanke, A., Rueger, D. C., and Cole, B. J. (2008). Response of human chondrocytes prepared for autologous implantation to growth factors. J. Knee. Surg. 21, 192-199.

Domayer, S. E., Trattnig, S., Stelzeneder, D., Hirschfeld, C., Quirbach, S., Dorotka, R., Nehrer, S., Pinker, K., Chan, J., Mamisch, T. C., Dominkus, M., and Welsch, G. H. (2010). Delayed gadolinium-enhanced MRI of cartilage in the ankle at $3 \mathrm{~T}$ : feasibility and preliminary results after matrix-associated autologous chondrocyte implantation. J. Magn. Reson. Imaging 31, 732-739.

Drobnic, M., Radosavljevic, D., Cör, A., Brittberg, M., and Strazar, K. (2010). Debridement of cartilage lesions before autologous chondrocyte implantation by open or transarthroscopic techniques: a comparative study using postmortem materials. J. Bone Joint Surg. Br. 92, 602-608.

Ebert, J. R., Robertson, W. B., Lloyd, D. G., Zheng, M. H., Wood, D. J., and Ackland, T. (2008). Traditional vs accelerated approaches to post-operative rehabilitation following matrix-induced autologous chondrocyte implantation (MACI): comparison of clinical, biomechanical and radiographic outcomes. Osteoarthr. Cartil. 16, 1131-1140.

Erggelet, C., Kreuz, P. C., Mrosek, E. H., Schagemann, J. C., Lahm, A., Ducommun, P. P., and Ossendorf, C. (2010). Autologous chondrocyte implantation versus ACI using 3D-bioresorbable graft for the treatment of large full-thickness cartilage lesions of the knee. Arch. Orthop. Trauma Surg. 130, 957-964.

Ferruzzi, A., Buda, R., Faldini, C., Vannini, F., Di Caprio, F., Luciani, D., and Giannini, S. (2008). Autologous chondrocyte implantation in the knee joint: open compared with arthroscopic technique. Comparison at a minimum follow-up of five years. J. Bone Joint Surg. Am. 90(Suppl. 4), 90-101.

Genovese, E., Ronga, M., Angeretti, M. G., Novario, R., Leonardi, A., Albrizio, M., Callegari, L., and Fugazzola, C. (2011). Matrixinduced autologous chondrocyte implantation of the knee: mid-term and long-term follow-up by MR arthrography. Skeletal Radiol. 40, 47-56.

Giannini, S., Buda, R., Vannini, F., Cavallo, M., and Grigolo, B. (2009). One-step bone marrow-derived cell transplantation in talar osteochondral lesions. Clin. Orthop. Relat. Res. 467, 3307-3320.

Gomoll, A. H., Probst, C., Farr, J., Cole, B. J., and Minas, T. (2009). Use of a type I/III bilayer collagen membrane decreases reoperation rates for symptomatic hypertrophy after autologous chondrocyte implantation. Am. J. Sports Med. 37(Suppl. 1), 20S-23S.

Gonda, K., Shigeura, T., Sato, T., Matsumoto, D., Suga, H., Inoue, K.,
Aoi, N., Kato, H., Sato, K., Murase, S., Koshima, I., and Yoshimura, K. (2008). Preserved proliferative capacity and multipotency of human adipose-derived stem cells after long-term cryopreservation. Plast. Reconstr. Surg. 121, 401-410.

Harris, J. D., Siston, R. A., Pan, X., and Flanigan, D. C. (2010). Autologous chondrocyte implantation: a systematic review. J. Bone Joint Surg. Am. 92, 2220-2233.

Hwang, N. S., and Elisseeff, J. (2009). Application of stem cells for articular cartilage regeneration. J. Knee Surg. 22, 60-71.

Kon, E., Delcogliano, M., Filardo, G., Montaperto, C., and Marcacci, M. (2008). Second generation issues in cartilage repair. Sports Med. Arthrosc. 16, 221-229.

Kon, E., Gobbi, A., Filardo, G. Delcogliano, A., Zaffagnini, S., and Marcacci, M. (2009). Arthroscopic second-generation autologous chondrocyte implantation compared with microfracture for chondral lesions of the knee: prospective nonrandomized study at 5 years. Am. J. Sports Med. 37, 33-41.

Kreuz, P. C., Müller, S., Ossendorf, C., Kaps, C., and Erggelet, C. (2009). Treatment of focal degenerative cartilage defects with polymer-based autologous chondrocyte grafts: fouryear clinical results. Arthritis Res. Ther. 11, R33.

Lee, K. T., Choi, Y. S., Lee, Y. K., Kim, J. S., Young, K. W., and Kim, J. H. (2010). Comparison of MRI and arthroscopy after autologous chondrocyte implantation in patients with osteochondral lesion of the talus. Orthopedics 33. doi: 10.3928/01477447-20100625-12

Malicev, E., Kregar-Velikonja, N., Barlic, A., Alibegovic, A., and Drobnic, M. (2009). Comparison of articular and auricular cartilage as a cell source for the autologous chondrocyte implantation. J. Orthop. Res. 27, 943-948.

Mithoefer, K., Hambly, K., Della Villa, S., Silvers, H., and Mandelbaum, B. R. (2009). Return to sports participation after articular cartilage repair in the knee: scientific evidence. Am. J. Sports Med. 37(Suppl. 1), 167S$176 \mathrm{~S}$.

Mobasheri, A., Csaki, C., Clutterbuck, A. L., Rahmanzadeh, M., and Shakibaei, M. (2009). Mesenchymal stem cells in connective tissue engineering and regenerative medicine: applications in cartilage repair and osteoarthritis therapy. Histol. Histopathol. 24, 347-366.
Moseley, J. B. Jr., Anderson, A. F., Browne, J. E., Mandelbaum, B. R. Micheli, L. J., Fu, F., and Erggelet, C. (2010). Long-term durability of autologous chondrocyte implantation: a multicenter, observational study in US patients. Am. J. Sports Med. 38, 238-246.

Munirah, S., Ruszymah, B. H., Samsudin, O. C., Badrul, A. H., Azmi, B., and Aminuddin, B. S. (2008). Autologous versus pooled human serum for articular chondrocyte growth. J. Orthop. Surg. (Hong Kong) 16, 220-229.

Niemeyer, P., Pestka, J. M., Erggelet, C. Steinwachs, M., Salzmann, G. M., and Südkamp, N. P. (2011). Comparison of arthroscopic and open assessment of size and grade of cartilage defects of the knee. Arthroscopy 27, 46-51.

Pinker, K., Szomolanyi, P., Welsch, G. C., Mamisch, T. C., Marlovits, S., Stadlbauer, A., and Trattnig, S. (2008). Longitudinal evaluation of cartilage composition of matrix-associated autologous chondrocyte transplants with 3-T delayed gadolinium-enhanced MRI of cartilage. AJR Am. J. Roentgenol. 191, 1391-1396.

Potter, H. G., Chong le, R., and Sneag, D. B. (2008). Magnetic resonance imaging of cartilage repair. Sports Med. Arthrosc. 16, 236-45.

Quirbach, S., Trattnig, S., Marlovits, S., Zimmermann, V., Domayer, S., Dorotka, R., Mamisch, T. C., Bohndorf, K., and Welsch, G. H. (2009). Initial results of in vivo high-resolution morphological and biochemical cartilage imaging of patients after matrix-associated autologous chondrocyte transplantation (MACT) of the ankle. Skeletal Radiol. 38, 751-760.

Rosenberger, R. E., Gomoll, A. H., Bryant, T., and Minas, T. (2008). Repair of large chondral defects of the knee with autologous chondrocyte implantation in patients 45 years or older. Am. J. Sports Med. 36, 2336-2344.

Rue, J. P., Yanke, A. B., Busam, M. L., McNickle, A. G., and Cole, B. J. (2008). Prospective evaluation of concurrent meniscus transplantation and articular cartilage repair: minimum 2-year follow-up. Am. J. Sports Med. 36, 1770-1778.

Saris, D. B., Vanlauwe, J., Victor, J., Almqvist, K. F., Verdonk, R., Bellemans, J., Luyten, F. P., and TIG/ACT/01/2000\&EXT Study Group. (2009). Treatment of symptomatic cartilage defects of the knee: characterized chondrocyte 
implantation results in better clinical outcome at 36 months in a randomized trial compared to microfracture. Am. J. Sports Med. 37(Suppl. 1), 10S-19S.

Saris, D. B., Vanlauwe, J., Victor, J., Haspl, M., Bohnsack, M., Fortems, Y., Vandekerckhove, B., Almqvist, K. F., Claes, T., Handelberg, F., Lagae, K., van der Bauwhede, J., Vandenneucker, H., Yang, K. G., Jelic, M., Verdonk, R., Veulemans, N., Bellemans, J., and Luyten, F. P. (2008). Characterized chondrocyte implantation results in better structural repair when treating symptomatic cartilage defects of the knee in a randomized controlled trial versus microfracture. Am. J. Sports Med. 36, 235-246.

Schmal, H., Mehlhorn, A., Stoffel, F., Köstler, W., Südkamp, N. P., and Niemeyer, P. (2009). In vivo quantification of intraarticular cytokines in knees during natural and surgically induced cartilage repair. Cytotherapy 11, 1065-1075.

Schmal, H., Niemeyer, P., Zwingmann, J., Stoffel, F., Südkamp, N. P., and Mehlhorn, A. T. (2010). Association between expression of the bone morphogenetic proteins 2 and 7 in the repair of circumscribed cartilage lesions with clinical outcome. BMC Musculoskelet. Disord. 11, 170. doi:10.1186/1471-2474-11170
Selmi, T. A., Verdonk, P., Chambat, P., Dubrana, F., Potel, J. F., Barnouin, L., and Neyret, P. (2008). Autologous chondrocyte implantation in a novel alginate-agarose hydrogel: outcome at two years. J. Bone. Joint. Surg. Br. 90, 597-604.

Steinhagen, J., Bruns, J., Deuretzbacher, G., Ruether, W., Fuerst, M., and Niggemeyer, O. (2010). Treatment of osteochondritis dissecans of the femoral condyle with autologous bone grafts and matrix-supported autologous chondrocytes. Int. Orthop. 34, 819-825.

Tohyama, H., Yasuda, K., Minami, A., Majima, T., Iwasaki, N., Muneta, T., Sekiya, I., Yagishita, K., Takahashi, S., Kurokouchi, K., Uchio, Y., Iwasa, J., Deie, M., Adachi, N., Sugawara, K., and Ochi, M. (2009). Atelocollagen-associated autologous chondrocyte implantation for the repair of chondral defects of the knee: a prospective multicenter clinical trial in Japan. J. Orthop. Sci. 14, 579-588.

Trattnig, S., Burstein, D., Szomolanyi, P., Pinker, K., Welsch, G. H., and Mamisch, T. C. (2009). T1(Gd) gives comparable information as Delta $\mathrm{T} 1$ relaxation rate in dGEMRIC evaluation of cartilage repair tissue. Invest Radiol. 44, 598-602.

Van Assche, D., Staes, F., Van Caspel, D. Vanlauwe, J., Bellemans, J., Saris, D.
B., and Luyten, F. P. (2010). Autologous chondrocyte implantation versus microfracture for knee cartilage injury: a prospective randomized trial, with 2-year follow-up. Knee Surg. Sports Traumatol. Arthrosc. 18, 486-495.

van Bergen, C. J., de Leeuw, P. A., and van Dijk, C. N. (2008). Treatment of osteochondral defects, of the talus. Rev. Chir. Orthop. Reparatrice Appar. Mot. 94(Suppl. 8), 398-408.

Welsch, G. H., Mamisch, T. C., Domayer S. E., Dorotka, R., Kutscha-Lissberg, F., Marlovits, S., White, L. M., and Trattnig, S. (2008). Cartilage T2 assessment at 3-T MR imaging: in vivo differentiation of normal hyaline cartilage from reparative tissue after two cartilage repair procedures - initial experience. Radiology 247, 154-161.

Welsch, G. H., Zak, L., Mamisch, T. C., Resinger, C., Marlovits, S., and Trattnig, S. (2009a). Three-dimensional magnetic resonance observation of cartilage repair tissue (MOCART) score assessed with an isotropic three-dimensional true fast imaging with steady-state precession sequence at 3.0 Tesla. Invest Radiol. 44, 603-612.

Welsch, G. H., Mamisch, T. C., Marlovits, S., Glaser, C., Friedrich, K., Hennig, F. F., Salomonowitz, E., and Trattnig, S. (2009b). Quantitative T2 mapping during follow-up after matrixassociated autologous chondrocyte transplantation (MACT): fullthickness and zonal evaluation to visualize the maturation of cartilage repair tissue. J. Orthop. Res. 27, 957-963.

Wondrasch, B., Zak, L., Welsch, G. H., and Marlovits, S. (2009). Effect of accelerated weightbearing after matrix-associated autologous chondrocyte implantation on the femoral condyle on radiographic and clinical outcome after 2 years: a prospective, randomized controlled pilot study. Am. J. Sports Med. 37(Suppl. 1), 88S-96S.

Zaslav, K., Cole, B., Brewster, R., DeBerardino, T., Farr, J., Fowler, P., Nissen, C., and STAR Study Principal Investigators. (2009). A prospective study of autologous chondrocyte implantation in patients with failed prior treatment for articular cartilage defect of the knee: results of the Study of the Treatment of Articular Repair (STAR) clinical trial. Am. J. Sports Med. 37, 42-55.

Zeifang, F., Oberle, D., Nierhoff, C., Richter, W., Moradi, B., and Schmitt, H. (2010). Autologous chondrocyte implantation using the original periosteum-cover technique versus matrix-associated autologous chondrocyte implantation: a randomized clinical trial. Am. J. Sports Med. 38, 924-933. 